\title{
Correction to: Safety and tolerability of eptinezumab in patients with migraine: a pooled analysis of 5 clinical trials
}

Timothy R. Smith ${ }^{1 *}$, Egilius L. H. Spierings ${ }^{2}$, Roger Cady ${ }^{3}$, Joe Hirman ${ }^{4}$, Barbara Schaeffler ${ }^{5}$, Vivienne Shen ${ }^{6}$, Bjørn Sperling ${ }^{7}$, Thomas Brevig ${ }^{7}$, Mette Krog Josiassen ${ }^{7}$, Elizabeth Brunner ${ }^{6}$, Loan Honeywell ${ }^{7}$ and Lahar Mehta ${ }^{5}$

\section{Correction to: J Headache Pain 22, 16 (2021) https://doi.org/10.1186/s10194-021-01227-5}

Following the publication of the original article [1], the authors notified us of a few data points that require revision (marked in red below):

Incorrect:

- Nearly one-third (32.4\%) of all patients were classified as obese (BMI $\geq 30 \mathrm{~kg} / \mathrm{m} 2$ ), and nearly half (48.9\%) had at least 1 cardiovascular risk factor at baseline.

- "Blood pressure increased" was noted for 39/2076 (1.9\%) patients who received eptinezumab and 14/

Author details

${ }^{1}$ StudyMetrix Research, LLC, 3862 Mexico Road, St. Peters, MO 63303, USA.

${ }^{2}$ Medvadis Research Corporation, Boston PainCare, Waltham, MA, USA. ${ }^{3}$ Lundbeck La Jolla Research Center, San Diego, CA, USA. ${ }^{4}$ Pacific Northwest Statistical Consulting, Inc, Woodinville, WA, USA. ${ }^{5}$ Lundbeck Seattle BioPharmaceuticals, Inc, Seattle, WA, USA. ${ }^{6}$ Lundbeck LLC, Deerfield, IL, USA.

${ }^{7} \mathrm{H}$. Lundbeck A/S, Copenhagen, Denmark.

Published online: 25 May 2021

\section{Reference}

1. Smith et al (2021) Safety and tolerability of eptinezumab in patients with migraine: a pooled analysis of 5 clinical trials. J Headache Pain 22:16. https:// doi.org/10.1186/s10194-021-01227-5 $791(1.8 \%)$ patients who received placebo, ...

Correct:

- Nearly one-third (32.4\%) of all patients were classified as obese (BMI $\geq 30 \mathrm{~kg} / \mathrm{m}^{2}$ ), and nearly half (48.8\%) had at least 1 cardiovascular risk factor at baseline.

- "Blood pressure increased" was noted for $14 / 2076$ (0.7\%) patients who received eptinezumab and 5/791 $(0.6 \%)$ patients who received placebo, ...

The original article has been corrected.

* Correspondence: tsmith@studymetrix.com

${ }^{1}$ StudyMetrix Research, LLC, 3862 Mexico Road, St. Peters, MO 63303, USA

Full list of author information is available at the end of the article

C C The Author(s). 2021 Open Access This article is licensed under a Creative Commons Attribution 4.0 International License, which permits use, sharing, adaptation, distribution and reproduction in any medium or format, as long as you give appropriate credit to the original author(s) and the source, provide a link to the Creative Commons licence, and indicate if changes were made. The images or other third party material in this article are included in the article's Creative Commons licence, unless indicated otherwise in a credit line to the material. If material is not included in the article's Creative Commons licence and your intended use is not permitted by statutory regulation or exceeds the permitted use, you will need to obtain permission directly from the copyright holder. To view a copy of this licence, visit http://creativecommons.org/licenses/by/4.0/ The Creative Commons Public Domain Dedication waiver (http://creativecommons.org/publicdomain/zero/1.0/) applies to the data made available in this article, unless otherwise stated in a credit line to the data. 